Дејан ДОНЕВ

У ДК:174:001.891

Изворен научен труд

\title{
ИМПЕРАТИВОТ ОДГОВОРНОСТ: ВРАК์АЊЕТО НА ЕТИКАТА ВО НАУКАТА
}

\section{Кратка содржина:}

Во екот на самозадоволството од техничко-технолоикиот прогрес во 20 век, како да се заборави дека науката и фихософијата започнуваат со чуденето, зачуденоста. Чудеюето, секако, во себе содржи и димензија на незнаене. Незнаеньето, барем според Аристотел, е незнаене на причината која хуѓето се обидуваат да ја дознаат. Така се раѓa науката, се отпочнуваат научните процеси, кои се слични и за време на решаването на геометриски, астрономски или проблеми од современата генетика.

Но, забрзаниот развој на техниката во 20 век едновремено му остави на човекот и една сосема нова морална ситуација на ширене на научните и технолошките достигнувань, еден процес кој е незапирлив антрополошки феномен затоа што тоа е онтолошка одредница со која настапува современиот човек. Опитеството, заедницата, навистина има тешка задача да балансира меѓу научната слобода на изразуваюе и одговорноста за чуване на социјалните норми и опитествените вредности.

Постоечките претежно хетерономни забрани, иако потребни, не се доволни доколку кај самите научниции не биде развивана свест дека треба да се следат опитите хуманистички морални начела и начелата на научната критичност, особено принциипот одговорност.

Клучни зборови: етика, одговорност, наука, истражуване, научник

\section{Вовед}

Доколку во моментов го анализираме квантумот и апликативната вредност на научното знаење со кое располага денешниот човек, се чини дека констатацијата „знаењето е моќ" (scientia potentia est) е апсолутно точна. Науката повеќе не е само скромен подвиг кој е продукт на една симбиоза помеѓу човековата природна ьубопитност и неговиот страв од природата, но и средство со кое тој би загосподарид со природата и би ги оттргнал прангите во кои е окован станувајќи слободен човек, лишен од сите маки и страдања. Во исто време, оваа констатација, во голема мера, е и 
апсолутно двосмислена - двете лица на римскиот бог Јанус: времето во кое живееме, и покрај тој голем квантум на знаења и зголемената апликативна вредност, сѐ уште се одликува со енормен број на нерешени проблеми кои како натрупан товар се влечат со децении и децении наназад, а се резултат на индолентниот однос и однесување на човекот во раздични сфери на живеењето.

Светот во кој денес живееме не претставува ниту обична екоиошка криза, ниту општество на ризик, туку станува збор за технолошки доста развиена цивилизација чиишто иновации би можеле да разорат многу повеќе отколку што ние сме во состојба воопшто да прогнозираме и за истото сносиме одговорност кон идните генерации. Доколку ги согледаме работите на овој начин, тогаш навистина станува збор за цивилизација која е преполна со опасности и општество кое ја загрозува својата иднина, при што со правилата на оваа цивилизација се прави непрестано создавање кумулативни долгорочни последици кои го доведуваат под прашање натамошното постоење на вистинскиот човечки живот на Земјата, бидејќи со своето константно загрозување иди дури загрозување на еколошките и социјално-културните темели на животот, воедно се загрозуваат уште повеќе и условите на слобода и преземање на одговорноста на идните генерации... (Bohler \& Gronke, 2003: 1077)

Од мноштвото проблеми поврзани со науката, посебно со истражувањата, а најмногу пред примената на научните истражувања ${ }^{1}$, доминираат оние што покажаа дека дури и најдобрите намери немаат добар резултат и последица (Arnaldi \& Bianch, 2016: 1), што реципроцитетно, значи и нужност од проширување и промена на подрачјето на моралот. Ова уште повеќе и поради фактот што моменталната поставеност на науката во современото општество доведе до една состојба во која знаењето истовремено може да биде и лек и болест, и според одреден број на автори „креираше вештачки свет кој носи поголем товар и од природата“ (Mitcham \& Briggle, 2005: 1061). Истиот на крај резултираше со актуализирање на дискурсот за потребата од пронаоѓање нов пристап, соодветни механизми за општествена и морална контрола на науката, како на самиот научноистражувачки процес, така и по однос на знаењата до кои се доаѓа во тој процес. Имено, сѐ повеќе се инсистира во научните истражувања повторно да се воведе етиката, нормативната етика, но не само како регулатор и „краен судија“ за она што се прави и применува, туку истовремено и како поттик за развивање етичка свест и совест за да не се случат стравични последици пора-

${ }^{1}$ На што укажуваат уште и Edward Diener \& Rick Crandall, Ethics in Social and Behavioral Research, University of Chicago Press, Chicago, 1978; како и Lucinda Peach, "An Introduction to Ethical Theory", in Robin Levin Penslar (ed.), Research Ethics: Cases and Materials, Indiana University Press, Bloomington, 1995, pp. 13-26. 
ди новата комерцијализација на науката (Krimsky, 1991). Па затоа и растат заложбите за „хуманизација“ на науката и техниката, наспроти воочдивите тенденции за идеодогизација на техниката и воведувањето на технократијата.

Сѐ поевидентни се заложбите за оживотворување на идејата за хуманизација на науката преку идејата за моралниот научник кој трага по вистината, без притоа да биде воден од потребата да фабрикува, фалсификува, погрешно интерпретира податоци, да го крие стекнатото знаење и да се оградува од последиците кои со своето истражување ги произведува во пошироката општествена заедница. Односно, научникот е „хуманата димензија“ на науката, мост помеѓу природата и општеството. Во оваа смисла е и идејата дека каков било акционен план за „зауздување“ на науката во суштина претставува редефинирање на улогата на научникот со потенцирање на одговорноста која е иманентна на неговата позиција како индивидуа со посебни способности, но и со реафирмирање на основните епистемодошки и методолошки принципи кон кои тој треба да се придржува при спроведување на научните истражувања, а кои се загрозени со перманентната приватизација на науката и зголемената академска конкуренција која води до квантитет, а не до квадитет.

Секако ова не значи занемарување на околноста дека науката како облик на моќ не зависи единствено и исклучиво од дикот на научникот, туку е потребно да се имаат во вид и другите чинители во севкупниот научен процес, како што се академските институции, истражувачките центри, издавачите на научните публикации, политичките фактори и јавното мислење, а кои имаат соодветна позиција во сликата за науката денес.

\section{Потребата од нов „одговорен“ пристап во научните истражувања}

Оваа состојба се јави како резултат на „попуштање на моралните узди“ поради општествените промени кои се случија, но и поради цела една низа на причини и настани, како и сѐ поголемата социјална фрагментација, а поради неа и опаѓањето на интензитетот на општествениот живот и јавниот ангажман, поради што, во генерална смисла, најмногу се обвинува промената на културниот процес и шаблон кој се појави и разви благодарејќи на постмодерната. Како што потенцира Зигмунд Бауман, владее „недоверба кон метанарациите“ (Bauman, 1993), која резултира со отфрлање на можноста за универзално, етички засновано нормирање. Докрај изведена теза, етиката е она што во светлоста на постмодернистичкиот релативизам се разбира како нешто што е „наменето за депонијата на историјата“ (Ваuman, 1993: 2). Крајната консеквенција е зародишот на новата смисла на парадоксот содржан во констатацијата на Жан-Жак Русо дека човекот се раѓа слободен, а насекаде е окован во пранги, само што претходниот „немидосрден господар - природата“", веќе е истиснат токму од она орудие кое требаше да го совлада - науката иди техниката како „применета наука“ 
која требаше да биде финадниот продукт од Беконовата идеја, новата врвна вистина. Сега науката се јави во улога на новиот господар!

Но, бидејќи постмодерната го направи најголемиот „грев“ во секоја од областите на човечката егзистенција и дејствување, рушејќи ја неговата индивидуалност и неповтордивост преку бришење на неговата автентичност и преку воведување на релативизмот на голема врата - сегашното барање за враќање на етиката и етичкото, и во истражувањата, ја изразува загриженоста на човекот наспроти неговата сегашност, но уште побитно, во однос на неговата иднина, во обидот повторно да ја пронајде својата есенција, смисла и цел на постоење. Тоа покажува, во делот на истражувањата, дека научниците, обидувајќи се етички да размислуваат за причините и последиците на своите истражувања, истовремено се обидуваат преку етиката да ја пронајдат и смислата на постоењето и оправданоста на резултатите до кои истите дошие. Токму поради тоа не е случајно што своевремено физичарот Карл фон Вајсекер жолчно инсистираше дека степенот на морална зрелост на научниците треба да се мери според продуктивната одговорност за последиците од сознанијата кои тие практично ги преземаат (Weizsäcker, 1980).

Ова произдегува од сознанието за високите стандарди кои етиката ги нуди, а кои се рефлектираат како повисок квалитет во/на истражувањата, со што во поголема мера се зголемува и општественото вдијание на истражувањата: промовирајќи истражувачки интегритет тие подобро ги усогласуваат истражувањата со општествените потреби и очекувања. Затоа е потребно пронаоѓае и повторно прифаќање на моралните оправдани причини поради кои се бара истражувањата да бидат подложени на етичка евалуација согласно системот на етичка оценка, бидејќи она што е суштинско е идентификување на потенцијална корист и ризик кои се јавуваат како резултат на исходиштето на истражувањето, а чија главна карактеристика е независноста (Bortolotti \& Heinrichs, 2007: 157 - 179).

Идејата е пред сѐ да се „постигнат четири работи“ и тоа „да се покаже практичката вредност на сериозното и систематско размислување за тоа што е и какво е тоа етично однесување во истражувањето“, понатаму „да се утврди како и зошто сме во ситуација на несфатливи појави од постоечките системи на регулација“, но и да се дојде до „расчистување на теренот и нагласување на оние акти кои доведоа до антагонизам помеѓу истражувачите и регулаторите“, како и да се направи „охрабрување на двете страни заеднички да осмислат решенија на етичките и регулаторните проблеми" (Israel \& Hay, 2006: 20). Оттука, од посебна важност е и натаму да се држи до гледиштето дека секое истражување не е интринсично етички сомнително во својата основа, бидејќи и покрај проблемите кои се јавуваат за време на неговото спроведување, постојат голем број на причини поради кои истото треба да биде поддржано и на него да се гдеда како на вредна активност. 
Имено:

- „истражувањето носи подобар квалитет на живеење и ја зголемува благосостојбата;

- поголем број на животи можат да бидат спасени;

- знаењето може да биде добро и поради самото себе“" (European Commission, 2010: 14).

Овие причини сега оправдуваат два раздично фундирани типови на одговорност во спроведувањето на истражувањето. „Првиот претставува етички аргумент - вонинтринсично вредносен - кој се гради на идејата за знаењето кое произлегува од добрата наука“" (European Commission, 2010: 14) и согласно кој истражувањето е вредно, корисно заради корисноста од знаењето кое се импдементира во општеството. „Вториот аргумент се однесува на идејата за знаењето како интринсично вредно, т.е. она што е само по себе вредно, независно од каква било понатамошна корист" (European Commission, 2010: 15) која би можела да се појави од неговата примена. ${ }^{2}$

Недостатоците на ваквите размисли, според повеќе современи автори, уште повеќе стануваат очигдедни со напуштање на строгата дистинкција помеѓу теоретската и апликативната наука, и со префрлање на фокусот од искдучиво теоретски истражувања кон истражувања поттикнати од промптната потреба за решавање одреден проблем. Ова укажува дека науката нужно во себе „апсорбира“ и екстерни или контекстуални вредности (кои не се од епистемодошка природа) изразени како општо добро, а кои најсуптилно се изразени во изборот на предметот на научен интерес. Кога на ова ќе се надоврзе и можноста одредено научно знаење иди пак патот (техниката) кој е употребен за да се дојде до него да доведе до негативни последици, неопходно е науката да се согледа во поширок општествен контекст и станува нужно да се редефинира етиката во науката, бидејќи принципот „не прави тоа што не сакаш да ти го прават“ веќе не е доволен.

Во овој контекст, Ханс Јонас е еден од првите кој ја препознава „дифузијата“ помеѓу теоријата и практиката и креира една нова „етика за технодошката доба“ (Hansen, 2006: 83) која веќе го нема во центарот пое-

\footnotetext{
${ }^{2}$ Во исто време, овие два раздично фундаментални типа на одговорност во спроведувањето на истражувањата во природните и општествените науки и нивната методологија на истражување, имаат раздична тежина и важност затоа што во општествените науки прашањето за изборот и моралната одговорност тежи, бидејќи нивните методи го немаат тој степен на вредносна неутралност, всушност идеалот на објективност, како во природните науки. Тука веќе е значително потешко да се направи дискрепанца помеѓу истражувачот и неговиот предмет на истражување, која ја чува објективноста, што нужно го поставува прашањето за слободата во активностите на човечкиот живот како клучна претпоставка за смислата на неговиот живот и вредности. Би се рекло дека во општествените науки проблемот на етичката евалуација на истражувањата е покомплициран поради прашањето за артикулација на слободата и нејзините граници бидејќи во такви истражувања не е можно да се избегне користењето на човечката индивидуа и деловите од општеството како материјал врз кој се спроведува истражувањето.
} 
динецот, туку се заснова на моралната одговорност на човештвото кон иднината - неограничена одговорност да се зачува животот на земјата, проектирана како спој на индивидуалната и општествената одговорност преку модификација на Кантовиот категорички императив: „Дејствувај така што последиците од твојата активност соодветствуваат со континуираноста на човековиот живот“ (Jonas, 1984: 11). Тргнувајќи од стојалиштето дека „силувањето на природата и култивирањето на човекот одат рака под рака“ (Jonas, 1984: 4), тој во центарот на етиката ја позиционира одговорноста и ја базира на околноста дека човештвото се движи кон амбисот и веќе не е возможно да ја контродира сопствена моќ над природата што ќе доведе до нејзина деструкција, особено во состојба кога човековите активности поврзани со технолошките процеси ги надминуваат временската и просторната рамка во кои е возможно да се антиципираат нивните последици.

Со други зборови, истражувањето може, а сега и мора методолошки да биде етично, а не само научно (Dawson \& Yentis, 2007: 165 - 176), што укажува на нужноста од пронаоѓње нови соодветни пристапи/модели на дејствување. Станува збор за нови и битно поинакви околности на општествениот живот чиишто импликации претставуваат предизвик за модерното општество и од нас оправдано бараат внимателно промислување на (био)етичката одговорност на човекот како поединец, но и како општествено суштество.

\section{За една етика на одговорност во новото време}

Чекор понатаму во претходното тврдење е фактот дека издезот од кризата е можен, но искдучиво како потсетување на оригиналните изворишта на науките, а во тие процеси философијата игра важна улога. Од особено значење е наследството од античката философска традиција. „Науката“ во античкото одредување (по примерот на Аристотел) претставува живот во вистината, како практичка последица од опсервацијата на суштината или вистината на стварите: „Сите луѓе по својата нарав тежнеат кон вистината“" (Aristotel, 1960: 980 а 1).

Со тоа на човекот му е потребна една нова, никогаш претходно придодадена димензија на одговорноста. Таквата одговорност како етичка категорија е битно раздична од поранешните антропоцентрични пристапи и истата е последица од цела една низа на нови животни околности и услови на опстанок. Се работи за етика во чијшто центар одговорноста е позиционирана и поткрепена со сознанијата дека човештвото се движи кон амбисот и веќе истото не е можно да ја контролира сопствената моќ над природата (што доведува и до нејзина пропаст). Затоа од круцијално значење е прашањето за одговорноста на научниците и философите, како суштинско прашање за научното дејствување, а не само како некое попатно прашање по клише кое може, но и не мора да се врзува со она што се случува на полето на науката и философијата. 
Ова прашање, уште повеќе, мора да биде она од што се поаѓа во секој научен и философски акт, со полна свест за можните злоупотреби и негативните последици кои може да следуваат од речиси секој резултат: „Денес научниците се во постојана потрага по финансиски средства за своите истражувања што најчесто прави истите да се насочуваат кон истражувања директно поврзани со решавање на одреден проблем од човечкото секојдневие, на сметка на „чистата“ наука, која е универзална основа за секое понатамошно истражување во одредено поле“" (Saenko et al., 2019: 336). Примери за овој недостаток на полна свест за одговорноста секојдневно може да се најдат во напорите несразмерно големо вложување средства да се инјектира во научните програми и проекти кои имаат практичка примена, односно во напорите значително малку средства да се дадат во т.н. „чиста наука“ (Seumas, 2013: 205), односно „во фундаменталните истражувања кои не носат моментална корист, туку овозможуваат развој на науката како таква“" (Bird, 2014: 170).

Сходно, причините за денешната криза и загриженост за последиците од наведените процеси лежат во пресудната, но не доволно нагласена дистинкција помеѓу откритието и примената на науките: „Што ќе направиме со знаењето кое науката го открива? Тоа не е работа на самата наука! Науката нема ништо со прашањето за доброто и здото, со задоводувањето на човечките желби... Оттука, нам ни паѓа одговорноста во име на науката да одлучиме што е вредно да се прави, пред да ја употребиме науката тоа да го направи“ (МасMurray, 1968: 36).

Паралелно, модерната научна бирократија и современите техничко-технодошки достигнувања и решенија во последно време значително напредуваат зафаќајќи ги сите сфери на природното, приватниот и јавниот живот - станувајќи сами на себе смисла, додека истовремено ја одземаат смислата во однос на поединецот, кому му станува сѐ потешко да го поими значењето на сопственото учество во споменатото случување. „Болеста на модерното доба се крие всушност во фактот за неспособноста на поединецот да ја разбере сопствената смисла, како и во недостатокот од интерес да биде упатен во тековната состојба на криза“ (Gretić, 1998: 145).

Во вакви околности, досега беа занемарувани сите останати можни повратни механизми на дејствување на човекот врз природата и светот околу себе, а последиците од таквиот однос денес се сѐ, освен занемарувачки. Накратко, она што би можело да го наречеме Беконова програма за господарење над природата со помош на науките и техниките, се заканува со општа катастрофа со големина на својот усnех. На врвот од триумфот се открива неговиот недостаток, противречноста и губењето на самоконтрола. На крај, денешниот човек не само што не е способен да ја заштити природата во целина, туку не е ниту способен да се заштити самиот себе си: Секој е причина, но и последица на своето исчезнување!

Следејќи ги размислувањата на Ханс Јонас, би можело да се каже дека ваквата ситуација е апсурд на модерното време, своевиден „парадокс 
на моќта“ во кој моќта над природата истовремено доведува до човеково апсолутно потчинување. Излезот од ваквата дијалектика на моќта е можен само преку воведување на следниот степен на моќта. Се бара „моќ над моќта" со која би ја вратиле под контрола сопствената моќ над природата и би се скршила нејзината тиранија над човекот (Jonas, 1990: 197-199). Токму затоа Јонас пледира (Jonas, 1985: 108) за една доброволна „самоцензура на науката во знакот на одговорноста која на нашата нарасната во голема мера моќ не смее да ѝ дозволи да нѐ совлада и нас самите иди оние кои доаѓаат после нас" (Jonas, 1985: 80). Па така, сето претходно поттикна засновање на етика, „етика за технолошката доба“" (Hansen, 2006: 83) која е способна да го постави прашањето за моралноста на научниците, нивната одговорност за научните откритија со штетни технолошки последици и морална вина на научниците технолози за последиците од техничката примена на науката, а кои веќе предизвикаа глобално загрозување на планетата и човекот. Значи една етика која веќе „го нема поединецот во центарот, туку се заснова на моралната одговорност на човештвото кон иднината - неограничена одговорност да се зачува животот на Земјата, проектирана како спој на индивидуалната и општествената одговорност“" (Jonas, 1984: 11).

Попрецизно, Јонас, свесен за опасностите од прогресивното нарушување на гдобалните компоненти на опстанокот на човекот и животот на планетата, разви една етика на одговорност која е распределена на три нивоа: индивидуално, професионално и макроетичко ниво, една „мрежа на одговорности" (Brall et al., 2017: 27-35) конституирана од раздични релации на моралните одговорности на научниците со други чинители во научниот процес, а кои релации се застрашувачки со растечката комерцијализација на науката. Па, обидувајќи се, го афирмираше налик на Кант, новиот етички категорички императив: „Дејствувај така што последиците од твоето дејствување да не бидат разорни за идната можност на таквиот живот" (Jonas, 1990: 28). Кон истото се приклучи и Макс Шелер со својата критика на позитивните науки од аспект на етиката на вредности велејќи дека науките, во својата квазинеутралност наспроти системот на вредности, мудро го кријат „научниот ум“ кој во научната постапка и апликација отстранува секакво морално и друго вреднување за волја на една единствена „вредност над вредностите“ - вредноста на моќта!

Значи, уште од самиот развој на модерната наука, па и подоцна, преовладуваше уверувањето на научниците дека науката како таква нема ништо со етиката: „науката не прави етички иди морални расудувања... Науката го обезбедува општеството со факти кои се релевантни за носење вредносни расудувања, но самата таа не се впушта во донесување морални одлуки“" (Rollin, 2006: 17 - 18). Уште повеќе, истата нема ништо ниту со кој и каков било телеолошки поглед на светот и дека научната работа со светот и животот мора да се одвива без политички или какви бидо други мешања во целосната слобода (Ehni, 2008: 149). 
Сепак, особено денес, сѐ повеќе е на сцена уверувањето дека науката не е вредносно неутрална. Не важи концепцијата за неутралност на науката која им служи на научниците криејќи се под плаштот на објективноста да ја избегнат одговорноста за негативните импликации од својата научна дејност. Науката сѐ повеќе е во тесна спрега со подитичката моќ, т.е. и самата претставува посебен вид на подитика на моќ затоа што низ научните институции истата е поврзана со доминантните владејачки средишта на моќта. ${ }^{3}$ Затоа, за моќта која ја имаат научниците, истите треба да понесат морална одговорност во својата научна работа и ангажман. Слободата на научното истражување мора да биде, како и секоја друга слобода, морално одговорна слобода. Се бара одговорно спроведување на научното истражување во кое секој научник треба „да следи однапред дефинирани етички стандарди и вредности при спроведувањето и објавувањето на истражувањето“" (Resnik \& Elliott, 2016: 31 - 46). Тие се оние кои се најкомпетентни да ги проценат ризиците кои со себе ги носат науката и техниката и повеќе од сигурно е дека токму тие се оние кои најдобро ги познаваат насоките и размерите во кои може да се прошири научното знаење. Оттука, произдегува должноста на секој научник да чекори низ истражувачкиот пат согласно утврдените етички принципи и да биде спремен да се носи со товарот на резултатите од своето истражување, да покаже морална волја да му возврати на човештвото за „честа“ која му е укажана и ресурсите кои се вложени во негова едукација.

Заклучно, без раздика на ваквите пред сѐ теоретски образдоженија, општоприфатен е ставот дека научникот како носител на посебна улога во општеството и „господар“ на посебното, специфично знаење, има должност не само да ја зголеми општата благосостојба, туку и да ги спречи негативните ефекти кои неговата активност може да ги има како врз поединецот, така и врз општеството во целина. Имено, со оглед на неговите способности научникот е оној кој најпрецизно (а во секој случај подобро од просечен човек и политичар) може да ги процени резултатите од своето истражување, да ги антиципира консеквенциите до кои стекнатото знаење може да доведе, како и да ја анализира врската помеѓу своето истражување и неговиот производ и да го смести во поширокиот општествен контекст. Едноставно, потребно е научникот да го почитува основното правидо дека науката во целина треба да го максимизира општото добро, а да ги минимизира можностите за уништување.

При ваква состојба, а особено кога се впушта во истражување кое резултира со знаење со двојна примена, научникот на некој начин балансира помеѓу „намерното добро“ и „предвидливото иошо““. Секако, секогаш е

\footnotetext{
3 За модерната наука како процес, а не како случуване, за тоа дека науката е креативна, а не втемелувачка и како таква треба да биде во сојуз со демократските промени и преобразби, а не со политиката на моќ, упатно е да се погледне Isabelle Stengers, The Invention of modern Science, University of Minnesota Press, Minneapolis, 2000.

${ }^{4}$ Интересни се размислите на Ханс Јорг Ехни за индиректната каузална одговорност на научникот за негативната употреба на знаењето кое е производ на неговата
} 
отворена можноста на долг рок да дојде до сосема неочекувани практични импликации од стекнатото знаење кое би внело несигурност во општеството и стои ризикот од настанување „Прометејски јаз“, термин кој Гинтер Андерс го користи за да ја опише „,асиметријата помеѓу подготвеноста за дејствување и способноста да се предвидат последиците од дејството“ (Arnaldi \& Bianch, 2016: 7), но тоа не го намалува значењето на оваа, на некој начин, „пророчка“ функција на научникот.

\section{Епидог}

Во екот на самозадоводството од техничко-технолошкиот прогрес во 20 век, како да се заборави дека науката и философијата започнуваат со чудењето, зачуденоста (Aristotel, 1988: b 11 - 21) . $^{5}$ Чудењето, секако, во себе содржи и димензија на незнаење. Незнаењето, барем според Аристотел, е незнаење на причината која луѓето се обидуваат да ја дознаат. Така се раѓa науката, се отпочнуваат научните процеси, кои се слични и за време на решавањето на геометриски, астрономски или проблеми од современата генетика.

Но, забрзаниот развој на техниката во 20 век едновремено му остави на човекот и една сосема нова морална ситуација на ширење на научните и технолошките достигнувања, еден процес кој е незапирлив антрополошки феномен затоа што тоа е онтолошка одредница со која настапува современиот човек. Општеството, заедницата, навистина има тешка задача да балансира меѓу научната слобода на изразување и одговорноста за чување на социјалните норми и општествените вредности. „Научната слобода... е стекнато право, општопризнато од страна на општеството и нужно за напредување на знаењето од кое општеството може да има корист“. Но „научната слобода и одговорност се суштински недвоиви“ (AAAS Committee on Scietific Freedom and Responsibility, 1975: 5). Со тоа, новата ситуација во која современиот човек мора да ја прими на себе одговорноста за делата кои не се резултат на дејствувањето на еден поединец, туку се колективен чин, „чин на анонимен субјект“, би рекол Хусерл, станува уште повеќе комплицирана. Истото е објаснето и преку констатацијата дека поголемата комплексност на човековото дејствување ја јакне и потребата за етичка рефлексија!

Несомнено е дека драматичните промени кои се случија во светот во последните неколку децении се резултат на развојот на науката, но не треба да се заборави дека тоа не е примарна цел на науката. Битниот мотив понаучна дејност. Повеќе во Hans Jorg Ehni, „Dual use and the ethical responsibility of scientists", Archivum Immunologiae et Therapiae Experimentalis, 56 (2008): 147 - 152.

5 За чудењето, зачуденоста како она што нѐ придвижува на философирање Аристотел пишува и во За небото 294 а 11 - 28, но и на други места. На истата тема пишува и Платон, во Теајтет (115 d) и во Филеб (14 c-e), но кај него чудењето е пред сѐ насочено на идејата (Парменид 129 c), додека кај Аристотел тоа е случај со сетилниот свет. 
ради кој луѓето влегуваат во науката, бил и несомнено сѐ уште е, потрагата по вистината, значи едно знаење заради знаењето! Во овој спој на мотиви кои се врзани за вистината и потрагата по неа, како и нејзините практички претензии, може да се детектира суштинската амбивалентност на науката и научниот развој. Современиот свет во моментов е несомнено обележан со натежнување на овој вториот елемент, практичкиот аспект на науката, односно ефикасноста од примената на нејзините резултати во секојдневниот живот на дуѓето, па затоа грижата и на науката и на научниците е најчесто фокусирана на што побрзо постигнување подобри резултати. Но, утилитаристичкиот момент секако не беше вечно обележје на науката и научниот развој. Потрагата по вистината, чудењето и љубопитноста претставуваат трајни особености на научната активност, нешто без што науката напросто не може. Практичката страна, од друга страна, е нешто што е попатно на науката, додека прашањата за суштината на човекот и неговиот свет се нејзина трајна, константна преокупација. Овие специфични човечки прашања играат главна улога во секој научен акт, истражување и експеримент.

Постоечките претежно хетерономни забрани, иако потребни, не се доволни доколку кај самите научници не биде развивана свест дека треба да се следат општите хуманистички морални начела и начелата на научната критичност. Оттука, потребно е прашањето за општествената одговорност на научниците да биде (био)етички кодифицирано, прашање кое поради својата адекватна интериоризација мора да биде и интегрален дел од образованието на научниците од најрани денови. Особено е важно научниците и фидософите во своите спознанија и согледби, а кои особено во хуманистичките науки често имаат карактер на вредносни уверувања, да не одат под достигнатите цивидизациски стандарди на етичко-морална култура и раздичните теми да ги промислуваат со должно внимание и свесност за дилемите со кои можат да се сретнат во својата професионална работа. 


\section{ПИТЕРАТУРА}

AAAS Committee on Scietific Freedom and Responsibility (1975). Scientific Freedom and Responsibility. Washington DC.: American Association for the Advancement of Science.

Aristotel (1960). Metafizika. Beograd: Kultura.

Aristotel (1988). Metafizika. Zagreb: Liber.

Arnaldi, S. \& Bianch, L. (2016). Responsibility in Science and Technology: Elements of a Social Theory, Futures of Technology, Science and Society. Wiesbaden: Springer Fachmedien.

Bauman, Z. (1993). Postmodern Ethics. Oxford: Blackwell.

Bird, S. (2014). "Socially Responsible Science is more than Good Science", Journal of Microbiology E Biology Education,15.2, 2014: 169-172.

Bohler, D. \& Gronke, H. (2003). "In dubio pro responsabilitate", Filozoska istraživanja, Vol. 23, No. 91.

Bortolotti, L. \& Heinrichs, B. (2007). "Delimiting the concept of research: An ethical perspective", Theoretical Medicine and Bioethics 28, No.3, 2007: 157179.

Brall, C. et al. (2017). "Research Ethics 2.0: New Perspectives on Norms, Values and Integrity in Genomic Research in Times of Even Scarcer Resources", Public Health Genomics, 20.1 (2017): 27-35.

Dawson, A. \& Yentis, S. (2007). „Contesting the science/ethics distinction in the review of clinical research", Journal of Medical Ethics 33, 2007: 165-176.

Diener, E. \& Crandall, R. (1978). Ethics in Social and Behavioral Research. Chicago: University of Chicago Press.

Ehni, J., H. (2008). "Dual use and the ethical responsibility of scientists", Archivum Immunologiae et Therapiae Experimentalis, 56 (2008): 147-152.

European Commission (2010). European Textbook on Ethics in Research. Luxembourg: Publications Office of the Europian Union.

Gretić, G. (1998). „Husserlova ideja Europe kao umne zajednice“, Politička misao, (XXXV) 2.

Hansen, B., T. (2006). "Academic and Social Responsibility of Scientists", ISYP Journal on Science and World Affairs, 2.2. (2006): 71-92.

Israel, M. \& Hay, I. (2006). Research Ethics for Social Scientists. London: SAGE.

Jonas, H. (1990). Princip odgovornost. Sarajevo: Veselin Masleša.

Jonas, H. (1985). Technik, Medizin, und Ethik-Zur Praxis des Princips Verantwortung. Frankfurt-M.

Jonas, H. (1984). The imperative of Responsibility: In Search of an Ethics for the Tehnological Age. Chicago: University of Chicago.

Krimsky, S. (1991). Biotechnics and Society - The rise of Industrial Genetics. New York: Praeger.

Mitcham, C. \& Briggle, A. (2005). „Humanization and dehumanization“, in: Encyclopedia of Science, Tehnology and Ethics, Vol.1, Carl Mitcham (ed.). Thomson Gale: Farmington Hills. 
Murray, M., J. (1968). Freedom in a Modern World. London: Faber and Faber.

Peach, L. (1995). "An Introduction to Ethical Theory", in: Research Ethics: Cases and Materials, Robin Levin Penslar (ed.). Bloomington: Indiana University Press.

Resnik, D. \& Elliott, K. (2016). "The Ethical Changes of Socially Responsible Science", Accountability in Research, 23:1 (2016): 31-46.

Rollin, B. (2006). Science and Ethics. New York: Cambridge University Press.

Saenko, N. et al. (2019). "The Social Responsibility of a Scientist: Philosophical Aspect of Contemporary Discussions", Journal of Social Studies Educational Research, 10.3 (2019): 332-345.

Seumas, M. (2013). "Moral Responsibility, Collective Action Problems and the Dual Use Dilemma in Scinece and Tehnology", in: On the Dual Uses of Science and Ethics: Principles, Practices and Prospects, Brian Rappert \& Michael Selgelid (eds.). Canberra: ANU Press.

Stengers, I. (2000). The Invention of modern Science. Minneapolis: University of Minnesota Press.

Weizsäcker, F., C. (1980). The Unity of Nature. New York: Farrar Straus Giroux. 
